\title{
AN OVERVIEW OF TAX POLICY AND ADMINISTRATION IN NIGERIA
}

\author{
Fatoki Jacob Obafemi Ph.D FCA \\ Department of Accounting and Finance \\ Ajayi Crowther University, Oyo \\ Nigeria.
}

DOI: http://dx.doi.org/10.38193/IJRCMS.2021.3407

\begin{abstract}
Tax administration is a body responsible for implementing and governing the tax laws and other tax related matter. They are held responsible for assessing, collecting and administering tax processes. For any nation desiring to be economically independent, such a nation must consider one of the major tools for economic development "TAX". It is one of the major fiscal policies used by the government in regulating the economy of the country and in increasing the income of government. The main objectives of this wok are to examine the problems and prospect of tax policy and administration in Nigeria. The methods of data collection are based on secondary sources and field survey by the researcher. The study consists of five chapters: section one covers the background of the study, statement of the problems, research objectives, research questions, research hypothesis, scope of the study, significance and limitations of the study. section two, literatures of different authors on tax administration and tax assessment were discussed: in section three, the methods adopted in carrying out the study were explained and likewise the research design, population of the study, research instrument and method of data collection. Section four involves mainly the data presentation and analysis, and the hypotheses already formulated were fully tested with ANOVA. Section five comprises of the summary, conclusion and recommendation that were suggested.
\end{abstract}

KEYWORDS: Policy, Taxation, Administration, Fiscal policy and Economic stability.

\section{Background to the Study}

Tax is one of the major fiscal policies used by the government in regulating the economy of the country and in increasing the income of government. Nigeria is a highly populated state with highly complex system. Nigeria system consists of tax law, tax administrative or tax management and tax assessment (Ariwodola J.A 2005).

Tax according to Agbetunde L. (2005), it is the "compulsory levy imposed by the government authority through economic agents on its subject or his property to achieved some specific goals.

This implies that tax is a compulsory levy that should be paid to government authorities either to the 
Federal Board of Inland Revenue Service (FBIRS), The State Board of Inland Revenue (SBIR) for increasing government income, reducing economic unhealthiness through financing of projects, distribution of wealth or wealth re-distribution and to encourage the consumption of locally made products. Taxation has evolved through stages in Nigeria. The tax system in Nigeria is a remarkable one as series of tax policies, tax law, tax administrative, tax penalties has been changed over time.

Tax policy is one of the elements of a good tax system. It refers to the set of rules, regulations methods adopted and adhered to in ensuring effective tax administration in Nigeria (Uzomaka I. 2009). The tax policy in Nigeria tax system is an essential element of the tax system as it involves:

- Regulation of tax comprising of laws regulating tax authorities,

- $\quad$ The changes in tax laws,

- $\quad$ Offences and penalties pronounced by the tax laws in Nigeria,

- $\quad$ An overview of flexibility in the tax system, advantages and disadvantages in the Nigeria tax system. Tax policy according to Federal Inland Revenue Service (FIRS 2011) is the "set of rules, principles, and strategies governing the collection, administration and efficiency of tax system in any economy or state.

Some of the tax laws in Nigeria are Company Income Tax (1961), personal Income Tax Act (1993), Company and Allied Matters Act (1990), Petroleum Profit Tax Act (1959), Capital Gain Tax Act (1967), Education Tax Act (1993), Value Added Tax Act (1993).

Tax Administration is the aspect of law which emphasizes the economic agents responsible for collecting tax on behalf of the government of a country (Uzomaka I. 2009). It is one of the important aspects of tax in Nigeria. Olasore (1998) opined that it is the "process of collecting and assessing tax in any economy.

Tax administration refers to the bodies such as the Federal Board of Inland Revenue, (FBIR), and the State Board of Inland Revenue (SBIR) responsible for collecting, assessing or charging individual or companies to tax in Nigeria. Tax administrative emphasized the:

- Roles of the tax authorities in Nigeria,

- Statutes governing them,

- The residence issues in Nigeria tax system,

- Strengthens and weakness of the administration of tax in Nigeria.

- The changes in tax administration in Nigeria, hence, this topic shall highlight the composition, functions, and rights of the different tax authorities in Nigeria. More so based on the scope of the study, shall purpose the changes in tax laws, scopes of tax system in Nigeria. 


\subsection{Statement of the Problem}

The empirical evidence supports that there is tax evasion, weak or acute tax provisions and insufficient professional in Nigeria tax system.

Due to these inadequacies in Nigeria tax policy and administration calls for the researcher findings solutions to the tax inefficiencies.

\subsection{Research Questions}

1. Did changes in tax laws have any significant relationship with tax revenue in Nigeria?

2. Tax evasion is not a major cause of tax inefficiency in Nigeria tax system?

3. Does lack of accountability and integrity of tax officials affect revenue base of the federal government?

\subsection{Objectives of the Study}

The major objectives of this study is to analyze the impact of tax administration, tax laws and problems in the Nigeria Tax System.

The other objectives of this study is highlighted below

- To examine the statutory roles of the tax authorities in Nigeria,

- To highlight changes in tax laws in Lagos State.

- To examine the causes of tax evasion and to reduce the insurgence of tax avoidance in the Lagos tax system,

- To pinpoint the relationship between the Nigeria tax system and European tax system.

\subsection{Research Hypothesis}

1 Changes in tax laws have significant relationship with tax revenue in Nigeria.

2 Tax evasion is a major cause of tax inefficiency in Nigeria tax system.

3 Lack of accountability and integrity of tax official affect revenue base of the federal government.

\subsection{Scope of the Study}

The study focuses mainly on the policy and administration in Nigeria, its problems and prospects using Lagos State as a case study.

Over the years, tax practices in Nigeria has been evidence or characterized with corruption, tax evasion, weak government policy and lower revenue base attribute to tax.

Thus, this study shall examine the causes of weak tax policy, effects of tax evasion and challenges of government officials in collection of tax.

Tax evasion which is a major cause of decay in our tax system shall be examined, its effect and how it can be minimized by the government authorities. 


\subsection{Significance of the Study}

This study is relevance to the government, students and companies in Nigeria and beyond. As a researchable topic, this would be of high significance to the government as it would give insight into the need for changes in tax law, need for widening the scope of the State Board of Inland Revenue.

This would assist government through recommendation in the study to make laws that will reduce tax evasion in Nigeria. Also, this study would give insight into the roles of the different tax authorities, the tax law, problems or weaknesses in Nigeria tax system and how to solve the problems. Also, to the companies, this study would give the importance attached to paying taxes and enlighten them on the penalties arrived to tax offences in Nigeria.

\subsection{Literature Review}

Arnold and Mclntyre (2002), define as a compulsory levy on income, consumption and production of goods and services as provided by the relevant legislation.

Policy according to Nwachukwu C.C (2005) is described as procedure and strategies in achieving stated objective Tax policy according to lipsey R.G. (1973) refers to a set of ruler, procedures, strategies adopted in regulating tax practices in Nigeria.

According to Agbatunde L (2005), Tax policy is the line of action adopted with fiscal objective intended by government in respect of taxation.

Tax laws are the legal instrument of fiscal policy derived from adopted tax policy.

Tax laws are set of rules, regulations and guiding principles governing regulating the administration, assessment of tax (Omolehinwa 2001).

Tax laws originate from judicial precedent, court decision, received English laws like common law, Equity and statue of general application.

The tax laws includes Company Income Tax Act 1990, Personal Income Tax Acts 1993, Petroleum Profit Tax Acts 1990, Capital Gain Tax Act 1990 (1990).

Tax administration according to Ojos (1998), involves the "interpretation and application of tax law into practices. This is the function of tax officials and tax consultants who assist payers in computing their taxes.

Tax administration according to Agbetunde $L$ (2005) refers to "Agents of government responsible for assessing tax payers and managing tax issues in a country".

The tax administrators involve the Federal Board of Inland Revenue (FBIR) which is an operational arm of the federal government responsible for tax assessment. They assess and collect company income Tax in Nigeria, Value added tax.

The State Board of Inland Revenue (SBIR) is the operational arm of the state government responsible for assessing tax at the state level (C.I.T.N 2008).

The administration of tax involves the human resources or personnel involved in tax 
assessment.

Tax administration involves some major activities. These activities are:

- Making of tax returns or information gathering

- Tax assessment

- Objections and appeals

- Collection and recovery of taxes.

The functions of tax administrators according to Joshua Oyebanji (2005) are:

- Computation of tax payable

- Communication of tax assessment

- Processing of objections and appeals

- Collection and recovery of tax,

- Accounting for tax collected, research and statistics

Organs of government refer to the tiers of government responsible for tax administration, tax financing in Nigeria. They include the federal government, state government and local government (Joshua Oyebanji 2005).

\section{$2.2 \quad$ Principles of Taxation}

The principles were suggested by Adam Smith. He called principles, "Cannon of Taxation". These principles of taxation are the underlying assumptions guiding tax practices in any economy. As principles, they must be adhered to by the tax payers and tax authorities in assessment and payment of tax. They include:

- Cannon of Equity

- Cannon of Flexibility

- Cannon of Production

- Cannon of Certainty

- Cannon of Convenience

The major principles in his book titled the "Wealth of Nations are:

- Equity

- Certainty

- Convenience

- Economy

- Flexibility

- The principle of Equity: States that everybody shows pay equal amount as tax. This cannon opines that since persons pay taxes, everyone should be treated equal right.

- Principle of Certainty: This principle states that the amount payable or chargeable, place of taxation and relevant tax authority should be certain. That is, there should be information availability and Knowledge of available resources or logistics in tax system. 
- Principle of Convenience: The principle states that the place of tax payment should be easily accessible. This implies that tax should be paid with ease without imposing unnecessary burden or hardship on taxpayers. This brought about the issue of residence in tax assessment to allow for tax assessment with ease.

- Principles of Economy: The cost of collecting tax shouldn't outweigh its benefit. Tax being a burden should be in line with cost/benefit analysis. If N100 is gotten as tax receipts, only $1 / 2$ or lower than this figure should be paid in getting taxable income by the relevant tax authority.

- The Principle of Flexibility: According to Adam Smith in his book titled the "Wealth of Nation" implies that tax should be easy to change from a system to another or from a method of tax to another method. There should be no traces of rigidly in tax system any economy.

\subsection{Tax Administration in Nigeria}

Nigeria tax administration had been following the pattern and form of the British tax administration. Nigeria is divided into three distinct but interacting tiers; Viz: Federal, state and local levels. The federal level performs a sort of coordinating and supervisory roles.

At each of these tiers are specific tax authorities charged with the responsibility of tax administration. These tax authorities are organs of tax administration established by federal laws of the land to administered tax on behave of government.

Under Nigeria constitution (1997), the power to legislate and impose taxes on incomes, profits, capital gains, and stamp duties (for individuals and companies) is vested in the federal government. Hence, federal government is given the exclusive power to enact laws imposing tax on individuals and companies in Nigeria.

However, the collection of the tax imposed is on the concurrent list as the three tiers of government share the power to collect the various taxes.

Tax administrator is the third and most important activity of taxation process. It is the actual or real practice of taxation. In as much as tax is compulsory levy, it has to be enforced by a legal statue. In fact, no tax is imposed without any enforcing law. It is the implantation of what these laws demand that results administration.

\section{Objective of tax administration}

1. Establishment of fiscal objective to pursue.

2. Designing most appropriate tax policy to achieve established objective. 
3. Implementation of established policy, efficiency, economically and effectively.

4. Monitoring and evaluation of implemented police. (CBA) feasible?

5. Ensure efficiency in actual administration.

\subsection{Organs of Administration}

\subsubsection{FEDERAL BOARD OF INLAND REVENUE (FBIR)}

FBIR was established by income Tax Administration Ordinance of 1958 (s.3) as the apex authority in the country.

Modifications were made by ITMA 1961, CITA 1979, and finance (Miscellaneous Tax Provisions) (Amendments) Decree 1993. The present composition and duties are as established in s.1 of CITA 1999. The operational arm of FBIR as Federal Tax Authority is the federal Inland Revenue service (FIRS) as established by law (s.1 (1) CITA 1979). This FIRS carries out the day-to-day routine activities of tax administration on behalf of the FBIR

\subsubsection{Powers and Duties}

- Administration of CITA and the PPTA

- Doing all things necessary and expedient for the assessment and collection of the taxes.

- Accounting for all amounts collected in a manner prescribed by the Minister of Finance.

- May acquire, hold and dispose any property taken as security for or in satisfaction of any amount due as tax or penalty and shall account for such property and the proceeds of sales thereof in a manner prescribed by the Finance Minister.

- May sue or be sued in its official name.

- May, by notice, authorized any person, within or outside Nigeria, to perform on its behalf any of its power or except it primary duties in the first schedule.

- May, with the consent of the minister, authorize joint tax board (ITB) to perform on its behalf, any of its power or duty including those in the first schedule

\subsubsection{Organization Structure of FIRS}

FIRS as the operation arm of the FBIR are responsible for the day-to-day activity of the board and carries out the decisions of the Board. It is responsible for assessment and collection of CIT \& PPT. The FIRS is divided into districts which are headed by an Assistant Director of taxes It comprises of three (3) departments, viz. Administration, assessment and collection.

Administrative Department: is responsible for staff matters (appointment, promotion, punishment, etc.), office maintenance and office routine matters.

Assessment Department: is responsible for raising assessments of the amounts payable as tax by the companies. 
Collection Department: is responsible for the collection of taxes assessed.

\subsection{State Board of Internal Revenue (SBIR)}

This is the tax authority at the state levy. It is in all states of the federation including the Federal Capital Territory (FCT) Abuja established by the finance (Miscellaneous Taxation Provision) Act No. 3, 19935.9 to administer tax in the state, its operational arm is the state Internal Revenue Service (SIRS) which shall be autonomous of the SBIR in the day to day running of the technical, professional and administration affairs.

\subsubsection{Composition (S.85h (2) Pita)}

1. The executive head of SIRS as chairman, who shall be a person experience in taxation appointed from within the SIRS by the Governor.

2. The directors and HODs within the state service.

3. A director from the state Ministry of finance.

4. The legal adviser to the SIRS.

\subsubsection{Modalities for Meeting}

1. Any five (5) members of the state Board, one of whom must be the chairman or a Director shall form a quorum.

2. Meeting shall be summoned by the secretary when business demands or at member's request.

3. Decisions shall be made by majority consent.

4. A majority decision of members in written by correspondence obtained by the secretary shall be treated as of made at actual meeting of the state Board, unless a member had requested such

\subsubsection{Duties}

1. Ensure effective and optimum collection of all taxes and penalties due to government under relevant laws.

2. Does all things deemed necessary and expedient for assessment and collection of tax.

3. Accounts for all amounts collected in a prescribed manner.

4. Appoints, promotes, transfers and impose discipline on employees of the state service.

5. Generally, controls and manages the state service on matter of policy subjects to provision of laws.

\subsection{The Joint Tax Board}

This is the main tax authority established by S.85(1) PITA saddled with the responsibility of personal Income Tax Administration as well as synchronizing and monitoring the state Boards. It was first established by section 27 (1) of ITMA 1961 as amended and later Section 85 (1) of PITA. 


\subsubsection{Composition}

1. The Chairman of the FBIR as the chairman.

2. One member from each state, being ma person experienced in tax matters, nominated by the commissioners in charge of Income Tax, either by name or office.

3. Legal adviser to FBIR to be in attendance as Adviser.

\subsubsection{Powers and Duties}

1. Advise the federal government on request in respect of double taxation arrangement concluded or under consideration with any other country and in respect of rates of capital allowance and other taxation matter having effect throughout Nigeria.

2. Promoter's uniformity in application of PITA and incidence of tax on individual throughout Nigeria.

3. Imposes its decision on any state for the purpose of confirming with agreed procedure or interpretation.

4. Considers and approves all pension schemes.

5. Releases list of approved tax list and other tax issues like list of double tax arrangement.

\subsection{Local Government Revenue Committee (S.85D (1)}

This is the tax authority established by PITA to administer (assess and collect) all taxes, fines and rates under its jurisdiction at the Local Government Level. It shall be autonomous of the Local Government Treasury which shall be its operating arm.

It is worth noting that Adamawa State Pioneered the established of Local Government Revenue Committee in Nigeria several years after the law requested for it.

\subsubsection{Composition}

1. Supervisor for finance as chairman.

2. Three (3) Local Government Councilors as members.

3. Two (2) other persons experienced in revenue matters nominated by the Local Government Chairman on their personal merits.

\subsubsection{Functions}

1. Assessment and collection of all taxes, fines and rate under its jurisdiction.

2. Account for all money collected in a manner to be prescribed by the Chairman of Local Government.

3. Responsible for the day-to-day administration of the Local Government Treasury.

\subsection{Joint State Revenue Committee}

This is a replica of the JTB. It is established by law (section 85F PITD, 1990) for the state of the federation. 


\subsubsection{Composition}

a. Chairman of the SBIR as the chairman.

b. The chairman of the Local Government Revenue in the state.

c. A representative of the Bureau on Local Government Affairs not below the rank of a Director.

d. A representative of the Revenue Mobilization Allocation and Fiscal Commission, as an observer.

e. The legal adviser of the SBIR.

\subsubsection{Functions}

1. Implements the decision of the JBT

2. Advises the JTB and the State and Local Government on revenue matters.

3. Harmonizes tax administration in the state.

4. Carries out other functions as many be assigned to it by the JTB.

\subsection{Board of Custom and Excise}

This is a body established under the custom and Excise Act to be responsible for the administration of customs and excise duties in Nigeria. Customs are taxes that should be paid to government of a country on goods bought from or taken to other countries while excise is a tax on certain goods manufactured and sold or used within the country. This Board is to assess and collect customs and excise in Nigeria. It is also expected to prevent smuggling of goods such that government revenue generation effort will be enhanced.

\subsection{Board of Appeal Commissioners}

This is a body authorized by Section 53 (1) of CITA and 59 (1) of PITD to be established by the Minister (Commissioner is to be established at the Federal level by the Minister to assist in the administration of tax especially in respect of objection and appeal procedure arising from taxes assessed by FBIR. Likewise, one is to establish in each state of the federation in respect of objection and appeal procedure arising from taxes assessed by the SBIR.

\subsection{The Problems and Prospects in Nigeria Tax System}

The tax administration in Nigeria has the following weakness and problems.

These problems are:

Poor Bookkeeping system: This is one of the movers causes of tax evasion in Nigeria. It is evident that tax system lacks proper record of amount paid by tax payers and tax chargeable. Inadequate Professional: There are less than 35,000 Chartered Accountant in Nigeria inclusive of Chartered tax practitioners, are not up to 60,000. This causes in propriety, embezzlement and absence of ethics in management of tax in Nigeria. 
- Low Level of Awareness or Orientation: Citizen of the country do not pay taxes due to their ignorance of the need to pay tax. Most of the few taxpayers who pay their tax liabilities due to the need to get government favor.

Hence, there is need for sensitization to awaken tax payers' consciousness to paying levies or tax in Nigeria.

- High Level of Illiteracy: Nigeria is among the developing countries in the world. Illiteracy is among the factors that make Nigeria a third world nation. Due to these problems, there are cases of evasion, and poor tax assessment.

- High Level of Tax Evasion: This is the major problem of tax authorities in Nigeria. This problem is evident to the extent that public operations owned by the federal government also evade tax. Evasion as eaten deep into our blood stream. For example, Nigeria Television Authority Edo and Chicken Republic was among the recognize firms sealed by the government for evasion of tax.

- Favoritisms in the Employment of Officials to Administer Tax: In any sector of government, there is favoritism and God-fatherism in the appointment of people. This has affected the quality of performances in Nigeria tax administration.

- Embezzlement and corruption among Tax officials: Public officials are known for corruption and embezzlement due to the problem of poor bookkeeping; embezzlement arose.

- Old Tax Laws: Nigeria tax laws are due for change. The rate of review of tax laws is low compared to the rate of review of tax laws in other European countries. This is shown in Nigeria old tax offices and penalties. Hence, there is need for a charge in tax system to align with foreign counterparts.

\subsection{Weaknesses of Tax Laws in Nigeria}

- It creates complexity and rigidity in tax administration,

- It discourages the use of initiative by tax professionals

- Tax laws are made by a group of people thereby creating an in-balance in tax administration.

- Since tax laws are made by some group of people, this implies that the tax laws only favors few group of people who made the laws.

- It costly to make laws: this due to the need to pay professional charges, sitting allowance and cost of reviewing laws in Nigeria is exorbitant.

- The tax laws in Nigeria is old and when often reviewed reflect little of latest development in tax.

\subsection{The Relevance of Tax Laws in Nigeria}

Due to the complexities in tax management in Nigeria there is need for making laws by the legislative arm of government to reduce the complexities and areas of differences among the 
authorities responsible for charging, assessing or collecting tax.

Tax laws is define by Chartered Institute of Taxation of Nigeria (CITN 2008) as the set of rules, principles, policies or codes of conducts regulating and governing the administration, assessment of tax system for an efficient tax system.

The Relevance of the tax law varies depending on the tax laws, the years it was made, changes in the law and those in charge of legislation of the divers' tax laws.

\section{The Relevance of Tax Laws is:}

- It Aids The Effective Administration of Tax: The Nigeria tax laws states that functions and scope of duties of the tax authorities in Nigeria.

- It Allows For Orderliness and Justice in The Nigeria Tax System: It is often said that "where there has to be proper documentation. The tax laws states what should be done by tax agents, the obligation of taxpayers, penalties or offences states for tax responsibilities. Hence, if anybody either government agents or tax authority negates their ethics or responsibility, sanction is melted to the defaulting party.

- Tax Laws Acts as Guides: There are pronouncements in the tax laws in fact everything done by tax authorities today is defined by the law.

\subsection{Solutions to Tax Problems in Nigeria}

- There is need for adopting and adhering to tax laws in tax management.

- The Unique tax identification number should be adopted in knowing the number of tax payers in any state of the federation.

- Proper Accounting system should be used in tracking tax charged and taxable profit at a given period.

- Tax receipt embezzled should be handle with strictness; the official involve in misappropriation of tax receipt should be published.

- There is need be to review our tax law to meet the recent standards or development in taxation.

- There should be full sensitization and orientation of tax payer to make them know their tax right and tax obligations.

- Favoritism should be removed in employment policies of tax authorities. This would ensure merit in tax administration and adherence to tax rules if favoritism is removed.

- The tax laws in Nigeria define the tax practices in the different state of the federation.

- Laws is at known general involves precedence. Hence, tax judgment made by the court of law in Nigeria enables individuals to know their right, highlight to tax offenders the what judgment are tenable in the court of law.

\subsection{Advantages of Tax in the Nigeria Tax System}

Tax is a compulsory levy impeded by the government on taxpayers ina any country or economy.

The impact of taxation in any economy varies but the unique advantages of taxation as a fiscal 
instrument according to AgbetundeLateef (2005) is a following.

a. Tax Aids Economic Growth: Taxation is one of the fiscal policies used in regulating the economy. A side from this, proceed from tax are invested in capital projects like construction of bridges, schools. The proceeds from tax is invested on professional who in the long run use their professional in promoting the image of their professional association. Income from tax is used in financing the deficit sector of the Nigeria economy.

b. It Aids Revenue Generation: This is the primary purpose of tax to ensure addition of funds to government purse. Hence, funds generated by government from petroleum profit tax, capital gain tax, personal income tax and company income tax if accumulated is okay to finance government project.

c. Useful in protecting infant Industries: Tax serves as a useful tool to protect infants industries. This could be in the form of charging imported goods higher tax. Tax could also achieve this advantage through granting of tax relief, tax holidays or allowances to the infant industries.

d. Useful in Discouraging the consumption of some harmful products: Tax could be used in discouraging the consumption of some harmful products by charging them higher tax and keeping close watch on the harmful or imported goods through issuing of ban.

e. It Aids Economic Stability: During inflation, tax is a useful tool in controlling or reducing the volume of money in circulation. The government could also make policies to charge some sensitive sectors a higher tax so as to achieve economic stability.

f. Income or Wealth Distribution: Tax could use as a useful tool in collecting from the rich and enriching the poor. This could be achieved through adoption of progressive tax system. In a country like Nigeria, since income or wealth is unevenly distributed, taxing the rich sector of the economy is a better way to restore income re-distribution.

\subsection{Economic Effects of Taxation}

1. Effects on Production: When there is high tax it reduces the tendency of companies to produce. When government wants to encourage the production of some goods and promote some companies, they resort to reducing excise tax and reduce export tax as well.

2. Effects on savings: When there is inflation, government uses tax to reduce the disposable income of working population. Hence, once disposable income is reduced, what remains for savings is also reduced.

3. Effects on inflation: Tax is used to reduce the volume of money in circulation in the economy. The effects of tax on inflation is to reduce inflation through inflationary measured (i.e. increase taxation). If tax is reduced; the resultant effect is increasing income, increased savings or consumption.

4. Effects on Consumption: There are inverse relations between tax and consumption. In a high tax economy, consumption will be adversely affected as disposable income will be low. There is low consumption where tax is high as disposable income would have been charged to tax. 
5. Effect on investment: Taxation if too high may discouraged investment generally as the amount of money in the hand of taxpayers is being depleted. Individual investment in certain areas may be encouraged (with low tax) or discouraged (with high tax) depending on the objective of government on such sectors of the economy.

\subsection{Use of E-Tax System in the Nigerian Tax System}

E-tax system refers to the electronic tax system. This is a system of carrying out tax functions through computer programmers' and packages.

The electronic tax system is the application of Information Technology in the Administration of Tax in Nigeria. (CITN 2008).

As a result of the complexities in the tax system, it is necessary to bring up a system to allow for simplicity in the tax system. It should be noted that information technology is applied to tax due to the changing nature of tax in the world, complexities in tax system, need for speed and accuracy in the tax system. The need for an efficient tax system also let to the advent of etax system in Nigeria.

One of the examples of e-tax system in Nigeria is the Tax Identification Number (TIN). This is a scheme used by the authorities in the administration of tax laws. This Identification number for tax purposes arose due to the need to curb tax evasion, track impropriety of tax system, and enhance efficiency in tax assessment in Nigeria.

The Tax Identification Number could be categorized into.

- Social Security Number (SSN)

- Employed Identification Number (ITIN)

- Preparer Taxpayer Identification Number (ITIN)

Section 86(9)(d) of the personal Income Tax Act, Cap P8, (FN 2007 and Section 8(q) of the Federal Inland Revenue Service (FIRS) establishment Act, 2007 provides for FIRS and SBIR to collaborate in issuance and administrating of tax identification number to all taxable persons (Individuals and corporate) body.

The tax identification number is mainly for identifying the number of taxpayers in Nigeria, hedge against tax evasion, and to bring tax practices in Nigeria in line with global tax practices in the world. The benefits accruable to administration of electronic tax system are:

i. It Aids Flexibility in Tax System: Unlike the manual administration of tax, the electronic tax system could be designed for any purpose ranging from assessment, to computation of taxable profit.

ii. It Allows for Professionalism in Tax System: Aside from the use of a tax system, it also allows for employment of tax consultants and chartered accountants vast in information technology to handle the electron tax system.

iii. E-Tax System can Handle much Data than Human Administrators: The electronic tax system is programmed in such a way to compile volume of data, computes assessable profit 
in batches, hence, it computes or assesses taxable profit of individuals and companies at a faster rate.

iv. There is Established Database: Data base is the collection of files in a single location. Electronic tax system makes it possible to access the taxable profit of persons or companies over a number of years. Aside from this, the computed tax system allows for easy accessibility to the file of a company or individual tax payer when there is a dispute between the tax authority and taxpayer.

v. Embedded in the Tax Identification Number: Is a package for computing the assessable profit of a taxpayer.

\section{Research methodology}

This section gives a description of the various methods that the researcher used in collecting data for achieving the objectives of the study on the Tax Policy and Administration in Nigeria, its Problems and Prospects. (A Case Study of Lagos State Government)

\subsection{Research Design}

This research was designed in a way that enabled the researcher to effectively collect and collate data for achieving the research purpose.

A descriptive and analytical research designs were in addition to qualitative and quantitative techniques to gather data for this research purpose. The quantitative technique involves the use of interview for gathering data. While the qualitative technique involves the use of questionnaire in gathering relevant data.

\subsection{Presentation and Analysis of Data}

The aspect of presentation of data and its analysis comes under this section. Different methods of presentation of data are available but for this study, frequency tables and pie chart graph were used to present information gathered through the questionnaire retrieved. The Analysis of Variance (ANOVA) was used to test the variances in the stated hypotheses in chapter one with the aid of computer software called SPSS i.e Statistical Package for Social Sciences version 20 which is the latest. T-test was also used to compare the men value of the variables. 


\subsection{Data Presentation}

Table 4.1: Respondents distribution by AGE

\begin{tabular}{|ll|l|l|l|l|}
\hline & & Frequency & Percent & $\begin{array}{c}\text { Valid } \\
\text { Percent }\end{array}$ & $\begin{array}{c}\text { Cumulative } \\
\text { Percent }\end{array}$ \\
\hline \multirow{3}{*}{ Valid } & 25-30 years & 46 & 55.4 & 55.4 & 55.4 \\
& 31-40 years & 19 & 22.9 & 22.9 & 78.3 \\
& 41-50 years & 18 & 21.7 & 21.7 & 100.0 \\
& Total & 83 & 100.0 & 100.0 & \\
\hline
\end{tabular}

Source: Field Survey, 2021

Comment: The above table shows that respondents within 25-30 years constitute the major population with $55.4 \%$, followed by respondents within $31-40$ years with $22.9 \%$ while $21.7 \%$ constitute respondents within 41-50 years.

Table 4.1: Respondents distribution by SEX

\begin{tabular}{|c|c|c|c|c|c|}
\hline & & Frequency & Percent & $\begin{array}{c}\text { Valid } \\
\text { Percent }\end{array}$ & $\begin{array}{c}\text { Cumulative } \\
\text { Percent }\end{array}$ \\
\hline Valid & $\begin{array}{l}\text { MALE } \\
\text { FEMALE } \\
\text { Total }\end{array}$ & $\begin{array}{l}40 \\
43 \\
83\end{array}$ & $\begin{array}{l}48.2 \\
51.8 \\
100.0\end{array}$ & $\begin{array}{l}48.2 \\
51.8 \\
100.0\end{array}$ & $\begin{array}{l}48.2 \\
100.0\end{array}$ \\
\hline
\end{tabular}

Source: Field Survey, 2021

Comment: The above table shows that female respondents were $51.8 \%$ while the male respondents constitute $48.2 \%$. This means that sex is not a barrier to tax administration.

Table 4.1: Respondents distribution by MARITAL STATUS

\begin{tabular}{|c|c|c|c|c|c|}
\hline & & Frequency & Percent & $\begin{array}{c}\text { Valid } \\
\text { Percent }\end{array}$ & $\begin{array}{c}\text { Cumulative } \\
\text { Percent }\end{array}$ \\
\hline \multirow{3}{*}{ Valid } & SINGLE & 18 & 21.7 & 21.7 & 21.7 \\
\hline & MARIED & 65 & 78.3 & 78.3 & 100.0 \\
\hline & Total & 83 & 100.0 & 100.0 & \\
\hline
\end{tabular}

Source: Field Survey, 2021

Comment: The above table shows that $78.3 \%$ respondents were married while single respondents constitute $21.7 \%$. The result shows that respondents who have responsibilities (families) are more in the tax administration job. 
ISSN 2582-2292

Vol. 3, No. 04 July-Aug; 2021

Table 4.4: Respondents distribution by NATIONALITY

\begin{tabular}{|c|c|c|c|c|c|}
\hline & & Frequency & Percent & $\begin{array}{c}\text { Valid } \\
\text { Percent }\end{array}$ & $\begin{array}{c}\text { Cumulative } \\
\text { Percent }\end{array}$ \\
\hline$\overline{\text { Valid }}$ & NIGERIAN & 83 & 100 & 100 & 100.00 \\
\hline
\end{tabular}

Source: Field Survey, 2021

Comment: The above table shows that all respondents are Nigerians.

\subsection{Test of Hypotheses 1}

Ho: Did changes in tax laws have any significant relationship with tax revenue in Nigeria?

Table 4.3.1 The penalty on tax evasion and other tax fraud are adequate

\begin{tabular}{|l|r|r|r|r|r|}
\hline & \multicolumn{1}{|c|}{$\begin{array}{c}\text { Sum of } \\
\text { Squares }\end{array}$} & \multicolumn{1}{c|}{ df } & \multicolumn{1}{c|}{$\begin{array}{c}\text { Mean } \\
\text { Square }\end{array}$} & F & Sig \\
\hline Between Groups & 38.452 & 2 & 19.226 & 14.081 & .000 \\
Within Groups & 109.234 & 80 & 1.365 & & \\
Total & 147.687 & 82 & & & \\
\hline
\end{tabular}

Source: SPSS version 20

Result: From table 4.3.1, the ANOVA result shows the asymptotic significant of 0.0001 which is less than $0.05 \mathrm{P}$-value, indicates that the test is statistically significant and have a goodness of fit. The Fstat (14.081) which is greater than F-critical value (3.111) at 0.05 sig.

Conclusion: Therefore, we accept that changes in tax laws have significant relationship with tax revenue in Nigeria.

\section{Hypothesis 2}

Ho: Tax evasion is not a major cause of tax inefficiency in Nigeria tax system

Table 4.3.3

\begin{tabular}{|l|r|r|r|r|r|}
\hline & \multicolumn{1}{|c|}{$\begin{array}{c}\text { Sum of } \\
\text { Squares }\end{array}$} & \multicolumn{1}{c|}{ df } & \multicolumn{1}{c|}{$\begin{array}{c}\text { Mean } \\
\text { Square }\end{array}$} & F & \multicolumn{1}{c|}{ Sig } \\
\hline Between Groups & 34.951 & 3 & 11.650 & 14.315 & .000 \\
Within Groups & 59.412 & 73 & .814 & & \\
Total & 94.364 & 76 & & & \\
\hline
\end{tabular}

Source: SPSS version 20 
Result: From table 4.3.3, the ANOVA result shows the asymptotic significance of 0.0001 which is less than $0.05 \mathrm{P}$-value, indicates that the test is statistically significant and have a goodness of fit. The F-stat (14.351) which is greater than F-critical value (2.730) at $0.05 \mathrm{sig}$.

Conclusion: Therefore, we accept that Tax evasion is a major cause of tax inefficiency in Nigeria tax system.

\section{Hypothesis 3}

Ho: Does lack of accountability and integrity of tax officials affect revenue base of the federal government?

Table 4.3.6

\begin{tabular}{|l|r|r|r|r|r|}
\hline & \multicolumn{1}{|c|}{$\begin{array}{c}\text { Sum of } \\
\text { Squares }\end{array}$} & \multicolumn{1}{c|}{ df } & \multicolumn{1}{c|}{$\begin{array}{c}\text { Mean } \\
\text { Square }\end{array}$} & F & \multicolumn{1}{c|}{ Sig } \\
\hline Between Groups & .808 & 3 & .269 & 4.469 & .006 \\
Within Groups & 4.759 & 79 & .060 & & \\
Total & 5.566 & 82 & & & \\
\hline
\end{tabular}

Source: SPSS version 20

Result: From table 4.3.6, the ANOVA result shows the asymptotic significance of 0.0001 which is less than $0.05 \mathrm{P}$-value indicates that the test is statistically significant and has a goodness of fit. The F-stat (4.469) which is greater than F-critical value (2.720) at $0.05 \mathrm{sig}$.

Conclusion: Therefore, we accept that lack of accountability and integrity of tax officials affect revenue base of the federal government.

\section{Summary}

For any nation desiring to be economically independent, such a nation must consider one of the major tools for economic development "Tax". It is one of the major fiscal policies used by the government in regulating the economy of the country and in increasing the income of government.

In Nigeria today, tax system consists of tax law, tax administration or tax management and tax assessment all of which are geared towards it economic development.

\section{Conclusion}

The tax system in Nigeria is a remarkable one as series of tax policies, tax law, tax administration, tax penalties have been changed over time. Even though, tax evasion, weak or acute tax provisions, lack 
of accountability and integrity of tax officials and insufficient professionals in Nigeria tax system administration in Nigeria. But one cannot erase the fact, that, due to these inadequacies in Nigeria tax policies and administration, government has done a lot to combat these problems by establishing various tax committees and tax institutions that will formulate good tax policy and effectively monitor the execution of those tax policies in order to promote standard of living of the public and ensure economic growth and economy development of the nation.

\section{Recommendations}

The following recommendations are suggested for proper action on tax administration in Nigeria.

1. Proper accounting system should be used in tracking tax charged and taxable profit at a given period.

2. Tax receipts embezzled should be handled with strictness. The officials involved in misappropriation of tax receipt should be published.

3. There should be review of tax laws to meet the recent standards or development in taxation.

4. The Unique Tax Identification Number should be adopted in knowing the number of taxpayers in any state of the federation.

5. There should be full sensitization and orientation of tax payers to make them know their tax rights and tax obligations.

6. Favouritism should be removed in employment policy of tax authorities.

7. Issues of tax evasion and avoidance should be treated strictly.

\section{REFERENCES}

AbiolaSanni LLM, FCTI: Bulleting for International Taxation 2011 (volume 65), No. 1 Published 22 ${ }^{\text {nd }}$ November, 2010.

AgetundeLateef A. (2004) "Principles and Practice of Nigeria Personal Income Tax", Feetal Consulting (Publishers), Lagos, Nigeria.

Brian J. Arnold and Michael J. McIntyre (2002), “International Tax Primer” Kluwer law international, The Hague, The Netherlands.

Chartered Institute of Taxation, Nigeria (2008), CITN Taxation Guides And Statues, Lagos, Nigeria. Glauier M.W.E and Underdown B. (2000) “Accounting Theory and Practice”, John Wiley and Sons, New York, USA.

ICAN Taxation Study Pack (2006), VI Publishing Limited, Lagos, Nigeria.

ICAN/ATS3, Taxation Study Pack (2006), VI Publishing Limited, Lagos, Nigeria.

James AdebisiAriwodola (2001), "Personal Income Tax in Nigeria”, JAA Nigeria Ltd, Lagos, Nigeria. Joshua O. Oyebanji (2010), "Principles and Practice of Taxation in Nigeria" Frontline Publishers, Adesola, Ibadan, Nigeria.

Lipsey R.G (1973), “An Introduction to Positive Economics”, English Language Book Society, U.K. Ola C.S (1982), "Income Tax Law and Practices in Nigeria”, Macmillan Ltd, London 
International Journal of Research in Commerce and Management Studies

ISSN 2582-2292

Vol. 3, No. 04 July-Aug; 2021

Omolehinwa Eddy (2001) “Government Budgeting in Nigeria”, Pumark Nigeria Ltd, Lagos, Nigeria. 